\title{
8. Water markets in the Murray-Darling Basin
}

\author{
R. Quentin Grafton \\ The Australian National University, Australia \\ James Horne \\ James Horne and Associates, Australia
}

\section{Introduction}

Efficiently allocating water across competing demands and allowing for its reallocation as circumstances change and environmental concerns gain higher priority are challenges faced around the world (United Nations 2011; World Water Assessment Programme 2012; Grafton et al. 2012a, 2012b). This chapter assesses the development and implementation of water markets in the MurrayDarling Basin (MDB), which involves five states and territories (Queensland, New South Wales, Victoria, South Australia and the Australian Capital Territory) and the federal Australian Government.

In recent research (Grafton et al. 2014), we addressed the development and current status of water markets in the MDB, described what provisions were made to secure environmental flows, and identified lessons learned.

\section{Review of water market development}

The creation of statutory rights for water first occurred in Victoria in 1886 and in New South Wales in 1888. Originally, it was envisioned that state governments would allocate water to meet explicit policy objectives (Martin 2005). Throughout the 1960s and 1970s, however, these water licences were altered to specify the amount of water that could be diverted. Eventually, water licences became shares in a consumptive pool. The bundle of rights incorporated in a water licence was eventually unbundled to the extent that we see today.

Water entitlements are an ongoing claim to a share of a water resource while a water allocation is the volume of water assigned to a particular entitlement in a specific water year. 
Reforms in 1994 separated water rights from land ownership and unbundled access and delivery rights, allowing for more trading flexibility. While allocation trade began in response to the 1982-3 drought and entitlement trade was permitted on a state-by-state basis starting in the late 1980s and early 1990s, the 1994 reforms allowed trade to increase significantly (Grafton et al. 2012a, 2012 b). Their implementation came at the same time that a cap was placed on total surface water abstraction in the southern part of the basin; this cap not only limited withdrawals but also preserved the reliability of existing water entitlements by ruling out new claims on water resources.

Reforms continued into the 2000s, albeit at a slower pace (Horne 2012). As water trading helped users cope with increasing scarcity, government agencies also took action to secure flows for the environment: $\mathrm{A} \$ 500$ million was provided in 2004 as part of the National Water Initiative, and droughts encouraged another A \$3 billion investment for environmental flow purchases in 2007. Equally important, the 2007 reforms established a Murray-Darling Basin Authority, and barriers to trade (such as interstate trade restrictions) were mitigated in order to improve competition within water markets and provide better information to buyers and sellers (Connell and Grafton 2011; Horne 2012).

\section{Status of water trading in the Murray-Darling Basin}

The trade in both entitlements and allocations within the MDB today represents about 80 per cent of all such trade in Australia. Entitlement trading in the southern part of the MDB peaked in 2008-9 (National Water Commission 2011:106). The allocation market, in contrast, has grown steadily over the past five years and, on average, represents 30 per cent of the total annual water allocation (National Water Commission 2011:74).

Government purchases of entitlements beginning in 2008 have made up a significant portion of entitlement trading (see Figure 1). Although entitlements are separated into several classes of reliability (the lowest of which suffers more severe cutbacks in allocations than the higher), prices for entitlements of each class have been relatively stable because they reflect future expectations and are therefore not influenced by short-term variations. In contrast, the price of allocations has tracked closely supply shocks. Figure 2 captures the price spikes; the impacts of widespread drought in 2008-9 saw the highest average prices (over A $\$ 400 /$ megalitres(ML)), while 2010-11, a relatively wet year, saw prices drop to A $\$ 20 /$ ML (National Water Commission 2011:34). 


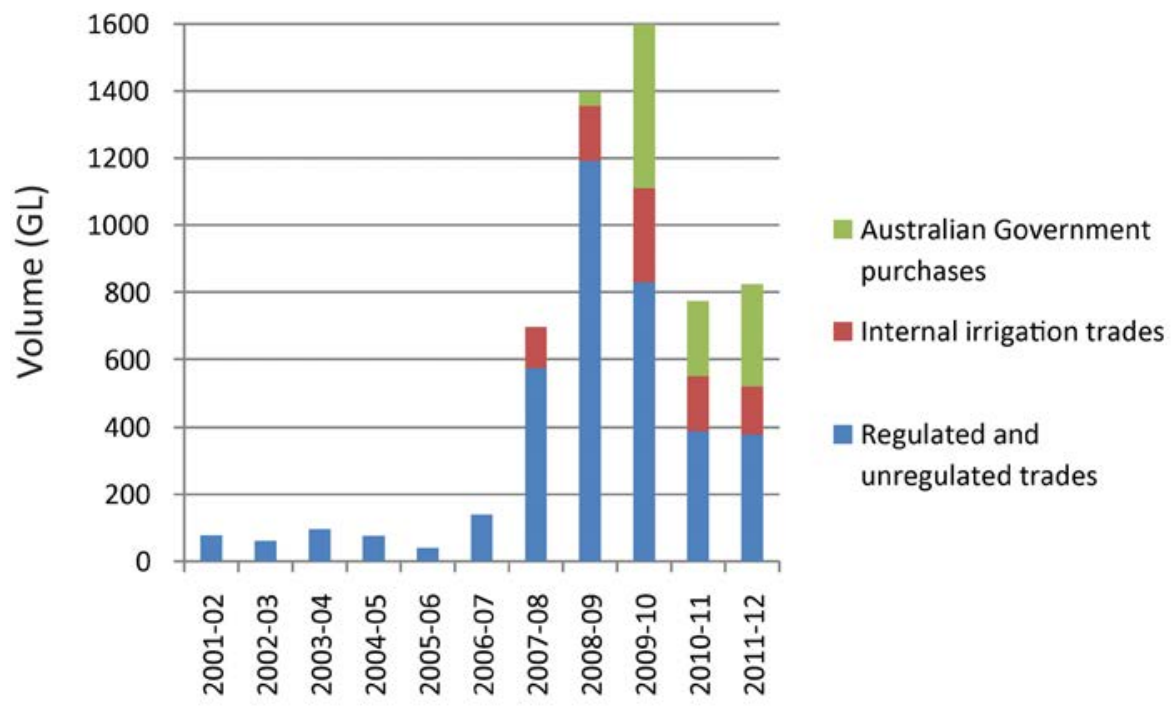

Figure 1: Water entitlement trade in the Southern Murrary-Darling Basin Source: National Water Commission (2013).

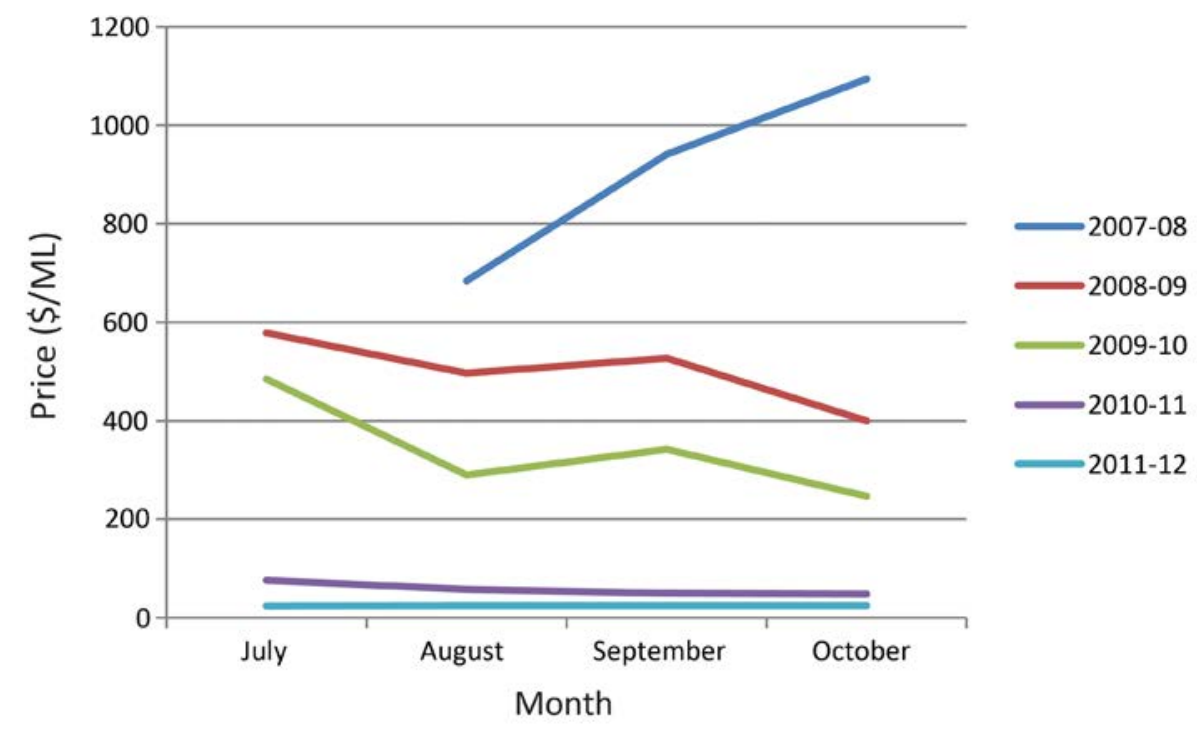

Figure 2: Average prices for water allocation trades in the Murray-Darling Basin (\$/ML)

Source: National Water Commission (2013). July 2007-2008 figures not available.

One major trade barrier, termination charges levied by irrigation districts, was addressed in 2010. The Australian Competition and Consumer Commission 
imposed rules that prohibit districts from hindering the devolution of entitlements to individual members and their sale thereafter. As a result, individual irrigators can now sell entitlements outside of the irrigation district without paying an arbitrary termination fee. Concerns on the part of districts that entitlement trading would imperil their financial stability haven't materialised because entitlement sellers have chosen to maintain water delivery contracts for allocation purchases (Australian Competition and Consumer Commission 2013).

In addition, remaining trading restrictions are being eliminated or loosened. As an interim step, state water trading rules override the rules established as part of the Basin Plan (Minister for Sustainability, Environment, Water, Population and Communities 2012:122). The Basin Plan will take full force between 2014-19. Once that occurs, the unbundling of statutory rights will be complete and entitlement trades will no longer be restricted based on water volumes or the purpose of use; restrictions to protect the environment will be assessed when users apply for local use licenses. The states meanwhile continue to restrict water entitlement trading volumes. For example, the government of New South Wales has imposed a three per cent limit on water entitlement purchases for environmental purposes that would in practice preclude future government purchases and is incompatible with Basin Plan rules. We argue that the resolution to this conflict will showcase how much enforcement power the Basin Authority possesses.

Despite barriers, gains from trade across the basin have been substantial. One estimate indicates that reallocation of water rights has boosted the gross regional product of the southern part of the basin by $\mathrm{A} \$ 370$ million (National Water Commission 2010). Meanwhile, risks to towns and cities are mitigated because, in the event of drought or other supply shocks, they can purchase allocation water on the market.

The provision of timely and accurate market information is important to facilitate trading. For this reason, the national government is establishing, in cooperation with the states, a National Water Market System (2014) to convey this information to market participants. Its implementation has been slow and inconsistent, however: months to years have elapsed without critical updates being made to the information system.

\section{Provisions for environmental flows}

The cap on water extraction instituted in the 1990s was designed to limit adverse environmental impacts, but the timing and location of extraction could be altered by trading. Over the period from 1998-9 to 2007-8, some waterways 
within the basin experienced increased end-of-system flows as a result of trading, and these flows helped protect ecological assets during the prolonged Millenium Drought (National Water Commission 2010).

A distinction should be made between two types of environmental flows. 'Rules-based' flows are those that remain after all entitlement holders have extracted their allocations. Allocations vary based on hydrologic conditions and the interests of individual states, so these flows are not a fixed proportion of available water. These flows were reduced more severely than irrigation allocations during the Millenium Drought (Commonwealth Scientific and Industrial Research Organisation 2008:59). This was one factor that prompted the national government to invest in 'entitlement' flows, or flows derived from entitlements purchased by the government for the purpose of improving environmental outcomes. Using the funds mentioned above as part of the reform packages, the Australian Government has closed contracts for over ten per cent of total water entitlements in the basin at an approximate cost of A \$2 billion (Department of Sustainability, Environment, Water, Population and Communities 2013). In addition, the government has funded water infrastructure projects designed to reduce water losses and subsequently direct the conserved water to the environment.

\section{Lessons learned}

Lessons learned can be summarised as follows:

- Crisis can serve as a focusing event - The severe droughts experienced in the basin prompted reform activity.

- Markets strengthen regional resilience - Trade-induced flexibility is improving outcomes for agricultural users, and entitlement portfolios for environmental flows are improving environmental outcomes.

- Leadership is necessary in the political realm - Basin-wide community support is indispensable, and political leadership is integral to implement market-based reforms.

- Extraction caps are paramount - Monitoring and enforcing surface water extraction caps strengthens water rights.

- Water storage facilitates trading - In addition to allowing downstream users to use allocation water on demand, water storage infrastructure extends the allocation trading season.

- Timely and accurate information facilitates trading — Participation can be encouraged by disseminating information on prices, which reduces uncertainty.

- Statutory rights provide a flexibile framework - Statutory rights allow for reform and reallocation without recourse to courts; one drawback is that 
policy changes can alter the value of statutory rights, but these changes can be appropriately compensated.

- Markets can secure environmental benefits - While increased end-of-system flows depend on the direction of water trade, governments can always undertake water acquisition for the environment.

- Water buybacks for the environment work - Government purchases of water entitlements in the market have helped acquire water more cost-effectively than alternative subsidy schemes (Productivity Commssion 2010; Qureshi et al. 2008; Grafton and Hussey 2007).

- Prices reflect scarcity and risk perceptions - Allocation water prices have tracked supply shocks closely, and the disparity between the prices of different classes of entitlements reflects future expectations of water allocation to particular entitlements.

- Inputs from local and basin-wide interests have different roles to play - Local input is useful to develop site-specific environmental recovery plans, but it can hinder the development of basin-wide markets; regional markets may require support from higher levels of government to overcome local interests.

- Monitoring and enforcement cannot be neglected - The initial cap in 1995 didn't control extraction from groundwater aquifers and other diversions, and this resulted in an undesired shift toward unregulated water sources.

\section{Conclusion}

A long reform process has unbundled statutory water rights into access entitlements, rights to annual allocation volumes, tradable delivery shares and non-tradable water use licenses that regulate how water is used at certain locations. These changes have enabled a water market to emerge that has successfully reallocated water throughout the MDB. Meanwhile, entitlement acquisition largely by governments has secured significant additional environmental flows. The success of market-based platforms depends to a great extent on their design. Governments must work with all stakeholders to establish a fair and efficient system. Infrastructure systems play a critical role in regulating the supply side of the market, and accurate information on supply volumes and trading prices underpins the demand side. After two decades of improving the regulatory framework, markets have become an important element of water provision in the MDB. They are helping water users and governments manage trade-offs between water use and the environment, particularly in dry years.

Dr R. Quentin Grafton FASSA is Professor of Economics, ANU Public Policy Fellow and Director of the Centre for Water Economics, Environment and Policy (CWEEP) at the Crawford School of Public Policy at The Australian National 
University. He is the Chairholder, the UNESCO Chair in Water Economics and Transboundary Water Governance and in August 2013 was appointed Executive Director at The Australian National Institute of Public Policy (ANIPP).

Dr James Horne is Principal of James Horne and Associates and a Visiting Fellow of The Australian National University. Between 2007 and early 2011, Dr Horne was Deputy Secretary in The Australian Department of Sustainability, Environment Water, Population and Communities, with responsibility for Water, where he led the development of water policy in the Australian Government. He was Chair of the Murray Darling Basin Basin Officials Committee and the Council of Australian Governments' Water Reform Committee.

\section{References}

Australian Competition and Consumer Commission, 2013. ACCC Water Monitoring Report 2011-12, March 2013. Available at: http://www.accc.gov.au/system/files/ Water\%20Monitoring\%20Report\%202011- 12.pdf.

Commonwealth Scientific and Industrial Research Organisation (CSIRO), 2008. Water Availability in the Murray-Darling Basin. A report to the Australian Government from the CSIRO Murray-Darling Basin Sustainable Yields Project, CSIRO, Canberra.

Connell, D. and Grafton, R.Q., 2011. 'Water reform in the Murray-Darling Basin', Water Resources Research, 47. Available at: http://dx.doi. org/10.1029/2010WR009820.

Department of Sustainability, Environment, Water, Population and Communities, 2013. Progress of water recovery under the Restoring the Balance in the MurrayDarling Basin program. Available at: www.environment.gov.au/water/policyprograms/entitlement-purchasing/progress.html.

Grafton, R.Q. and Hussey, K., 2007. 'Buying Back the living Murray: at what price?', Australasian Journal of Environmental Management, 14:74-81.

Grafton, R.Q., Pittock, J., Davis, R., Williams, J., Fu, G., Warburton, M., Udall, B., McKenzie, R., Yu, X., Che, N., Connell, D., Jiang, Q., Kompas, T., Norris, R., Possingham, H. and Quiggin, J., 2012a. 'Global insights into water, climate change and governance', Nature Climate Change, 3:315-21.

Grafton, R.Q., Libecap, G.D., Edwards, E.C., O'Brien, R.J. and Landry, C., 2012b. 'Comparative assessment of water markets: insights from the Murray-Darling Basin, Australia and the Western USA', Water Policy, 14:175-93. 
Global Water: Issues and Insights

Grafton, R.Q. and Horne, J., 2014. 'Water markets in the Murrary-Darling Basin', Agricultural Water Management (In-Press). Available at: DOI: 10.1016/j. agwat.2013.12.001

Horne, J., 2012. 'Economic Approaches to Water Management in Australia', International Journal of Water Resources Development, 29(4):526-43. Available at: DOI:10.1080/07900627.2012.712336.

Martin, W., 2005. Water Policy History on the Murray River, Southern Riverina Irrigators, Deniliquin, New South Wales.

Minister for Sustainability, Environment, Water, Population and Communities, 2012. Explanatory Statement, Basin Plan 2012. Canberra. Available at: www.mdba.gov. au/sites/default/files/Basin-Plan/Explanatory-Statement-Nov2012.pdf.

National Water Commission, 2010. The Impacts of Water Trading in the Southern Murray-Darling Basin, Commonwealth of Australia, Canberra.

-, 2011. Water Markets in Australia: a short history, Commonwealth of Australia, Canberra.

-, 2013. Australian water markets: trends and drivers 2007-2008 to 2011-2012, Commonwealth of Australia, Canberra.

National Water Market System, 2014. Website of the National Water Market System. Available at: http://www.nationalwatermarket.gov.au/.

Productivity Commission, 2010. Market Mechanisms for Recovering Water in the Murray-Darling Basin, Final Report, Canberra.

Qureshi, M.E., Schwabe, K., Connor, J. and Kirby, M., 2008. 'Environmental water incentives policy and return flows', Water Resources Research, 46. Available at: http://dx.doi.org/10.1029/2008WR007445.

United Nations, 2011. Water in the Green Economy in Practice: Towards Rio+20, Conference Book, International UN-Water Conference, 3-5 October 2011. Available at: www.un.org/waterforlifedecade/green economy 2011/.

World Water Assessment Programme (WWAP), 2012. The United Nations World Water Development Report 4: Managing Water under Uncertainty and Risk, Paris, UNESCO. 
This text taken from Global Water: Issues and Insights by R. Quentin Grafton, Paul Wyrwoll, Chris White and David Allendes, published May 2014 by ANU Press, The Australian National University, Canberra, Australia. 